\title{
Economic Crisis and Lawmaking. The Impact of Crisis on Legislative Agenda in Italy
}

\author{
Andrea Pedrazzani ${ }^{1}$, Alessandro Pellegata ${ }^{2}$ and Luca Pinto ${ }^{3}$ \\ ${ }^{1}$ Università di Bologna Alma Mater Studiorum, Department of Political and Social Sciences \\ Strada Maggiore 45, 40125, Bologna (Italy) \\ Email: andrea.pedrazzani@unibo.it \\ ${ }^{2}$ Università degli Studi di Milano, Department of Social and Political Sciences \\ Via Conservatorio 7, 20122, Milano (Italy) \\ Email: alessandro.pellegata@unimi.it \\ ${ }^{3}$ Università di Bologna Alma Mater Studiorum, Department of Political and Social Sciences \\ Strada Maggiore 45, 40125, Bologna (Italy) \\ Email: luca.pinto@unibo.it
}

\begin{abstract}
Andrea Pedrazzani is adjunct professor of Political Science at the University of Bologna. He previously got a Ph.D. in Political Studies (2011) at the University of Milan and was visiting scholar at the University of Mannheim (2009) and at the London School of Economics and Political Science (2012). His research interests include parliamentary processes, political representation, electoral behaviour and quantitative methods for the social sciences. He has published articles in the European Journal of Political Research, Government and Opposition, the Journal of Legislative Studies, Legislative Studies Quarterly, Parliamentary Affairs, Party Politics, Political Studies, South European Society and Politics, the Italian Political Science Review, and Comunicazione Politica.
\end{abstract}

\begin{abstract}
Alessandro Pellegata is a research fellow at the Department of Social and Political Sciences of the University of Milano (Italy). His main research interests are in the field of comparative politics, in particular electoral competition, public opinion and legislative politics. He has published articles in several academic journals, such as Democratization, International Journal of Public Opinion Research, International Political Science Review, Journal of Information Technology \& Politics and Social Indicators Research.
\end{abstract}

Luca Pinto is a Research Assistant at the Institute of Social Sciences and Humanities, Scuola Normale Superiore, Firenze (Italy), and adjunct professor at the University of Bologna (Italy). His research interests include party competition, legislative studies, and coalition governments. He has published on these topics several contributions in books and international journals.

Funding: This work was supported by the Italian Ministry for Education, University and Research, with the grant [2015P7RCL5], 'Politics and Policy in Europe in times of crisis: Causes and consequences'.

Acknowledgements: An earlier version of this article was presented at the Second International Conference on Public Policies, held at the Catholic University of Milan, 1-4 July 2015. We thank all participants for discussing the article. We also thank two anonymous referees for their helpful comments and suggestions, and Marco Giuliani and Francesco Zucchini for substantial comments on an earlier draft of this paper.

Wordcount: 8,456 excluding title page, tables, figures and appendix 
Abstract: Major economic crises are focal events that often drive changes in various aspects of political systems. Although extensive work has been done to investigate the effect of exogenous shocks on political phenomena such as government termination, public opinion and policy outcomes, the impact of major crises on the process of policymaking has so far received scarce attention. Building on existing literature on policy agendas and legislative organization, this paper explores how the Eurozone crisis has affected the legislative agenda of the Italian parliament. The data used include information on the 1,110 bills submitted to parliament during Legislature XVI (2008-2013). Our analysis shows that, with the worsening of the crisis, bill proposals related to macroeconomic issues become increasingly more likely to enter the legislative agenda, displacing legislation dealing with other topics. Our argument is corroborated by a comparison between Legislature XVI and a pre-crisis legislature (20012006), as in the latter term the legislative agenda follows different patterns. 


\section{Introduction}

Big economic crises are typically described as dramatic events that perturb the ordinary state of affairs and hence are hardly disregarded by key actors in a political system. Crises do not only alter the state of the economy, but also represent shocks to the environment where political decision-making takes place. Such crises can have important reverberations inside political systems, where often some distinguishable actions are taken in response to changing external conditions. In the political science literature, external shocks like economic crises have been framed as "windows of opportunities" where circumstances become favourable to major policy change (Keeler, 1993; Kingdon, 1984), or as "critical junctures" whose outcomes are crucial for the path followed by political processes in subsequent times (Collier and Collier, 2002; Pierson, 2000; Thelen, 2004). It is then a widespread notion that exogenous shocks, such as economic crises, (re-)shape political decision-making processes by changing the external context in which they take place.

Focusing on Italy, a country deeply affected by the sovereign debt crisis that started in late 2009, this paper aims at investigating the effect of the crisis on the policy agenda of parliament. The Eurozone's economic downturn has unsettled well-established patterns of party competition especially in Southern Europe, where the crisis has led to electoral instability and, later, has produced changes in consolidated and (up to then) predictable dynamics of cabinet formation and termination. At the same time, scholars in public policy have highlighted the capacity of the crisis to trigger processes of change inducing phenomena of policy convergence among systems with different institutional traditions (Sacchi, Pancaldi and Arisi 2011). This perspective is grounded in the literature on policy convergence under conditions of financial globalization (Garrett 1998), which has stressed the role of international capital mobility as the main force that limits governments' economic policy autonomy. National executives tend to opt for actions that are welcomed by market actors, leading to an increasing similarity in the 
policies enacted in different countries. The tension between governments' responsibility towards market forces and responsiveness towards their voters has been deepened by the crisis, spreading across Europe a contagion that first appeared in electoral politics and then affected parliamentary and government levels (Bosco and Verney 2012, 2016).

According to a number of scholars the result of this process is the development of a "democracy without choices" (Bosco and Verney 2012, p. 151), where the predictability of economic policy outcomes often clashes with the demands of voters. In this paper, we extend this notion to the study of the parliamentary agenda in time of crisis. Exogenous shocks, triggered by worsening economic conditions, bring a reallocation of political attention across different issues (Jones and Baumgartner 2005). However, since time is a scarce resource in parliaments, decision-makers have to choose how to allocate their time and efforts in the policymaking process. If they respond to external pressures by prioritising economic policies designed to face the crisis, almost no time could be left in the parliamentary agenda for other topics. In other terms, under economic hardship we can expect that political actors have a low room of manoeuvre in the selection of the policy domains that enter the agenda, so that economic polices monopolise the parliamentary works.

This paper examines the conditions under which bill proposals are more likely to enter the legislative agenda by analysing Italian Legislature XVI (2008-2013), during which the economic crisis has burst. To what extent has the crisis altered the way in which political institutions make key decisions? Did such a major shock alter the priorities of political actors and hence the distribution of legislative attention across policy domains? More precisely, which policy issues were better able to get it through the parliamentary process and were eventually advanced onto the debate agenda of the assembly throughout the crisis? Our analysis provides evidence that, with the worsening of the Eurozone crisis (i.e. during Legislature XVI), bills related to macroeconomic issues became increasingly more likely to enter the legislative 
agenda, displacing legislation dealing with other topics. As expected, the same did not happen during a pre-crisis legislature (XIV, 2001-2006), which we used to corroborate our findings.

This paper is organised as follows. In the next two sections we discuss the main theoretical contributions on agenda selection in time of crisis and derive our hypothesis. Section 4 provides a brief outline of the economic and political impact of the debt crisis in Italy in the 2008-2013 period. Data, methods and coding are introduced in section 5. The main findings of our research are presented in section 6. Concluding remarks follow in the final section, where we draw a number of possible implications of this paper for legislative studies and future research on crisis politics.

\section{Literature review}

Major economic crises are focal events that drive changes in various aspects of the political system. Scholars have extensively investigated the consequences of crises on public opinion and electoral behaviour (Lindvall, 2014; Singer, 2013), as well as on the conduct of elected representatives (Blumenau and Lauderdale, 2017; Moury and De Giorgi, 2015). However, crises affect other aspects of the functioning of national democratic institutions, not least the decision-making processes within those institutions (Morlino and Quaranta 2016). To examine how domestic policies are made during crises, we concentrate on the legislative arena, as all the key decisions in a political system typically pass through the parliament.

Although an increasing number of works are exploring the specific policy changes induced by the austerity approach that was promoted by the European Union (EU) in facing the recent crisis, much less scholarly attention has so far been paid to the effects produced by the crisis on the political processes leading to those policy changes. In this regard, a growing research program on the dynamics of policy agendas in democratic countries can offer some useful insights (Baumgartner and Jones, 1993; Green-Pedersen and Walgrave, 2014; Jones and 
Baumgartner, 2005). According to this perspective, policy agendas are defined as "the set of issues that are the subject of decision making and debate within a given political system at any one time" (Baumgartner, 2001, p. 288). Focal events like dramatic economic downturns can help explain "punctuated" dynamics of change in the agenda of public decision-makers. ${ }^{1}$ Policymaking is characterised by long periods of incremental change or near stasis, punctuated by brief periods of disequilibrium, where certain issues spill over into the agenda of political actors and large-scale policy change takes place.

In this theoretical perspective, executives and legislative bodies make decisions based on the information they collect from the social environment, and policy changes spring from shifts in attention across policy issues. When new issues arise, or when some existing issues gain more attention in the public discourse, extant policies can be questioned. In this case, the old policymaking equilibrium is destabilised and radical departures from the past can be realised. In other words, major policy shifts can occur not only after new general elections, but also during inter-electoral periods, when legislators' policy preferences are stable. Consequently, dramatic events like the global economic crisis can be expected to bring about a significant re-allocation of political attention among issues, together with a re-definition of the agenda of key political actors. Following Jones and Baumgartner's (2005) work on the "politics of attention", a number of empirical studies have examined how and why certain issues are prioritised over others and enter the agenda of public decision-makers (Alexandrova, Carammia and Timmermans, 2012; Borghetto and Carammia, 2015; Jennings et al., 2011; Jones and Baumgartner 2004).

In order to study how the economic crisis has affected the policy agenda of the Italian parliament, we also require some theoretical insights into the decision-making process in parliaments, which are almost lacking in the literature on policy agendas. Grounded on rationalchoice institutionalism, a well-developed body of scholarship explains the emergence of 
legislative organisation as a response to problems arising in representative assemblies - among these, the scarcity of time. Modern legislative assemblies are busy institutions that attend to several important activities ranging from policymaking to constituency services. However, they have only a limited number of sitting days in order to perform these tasks, as the maximum length of the legislative term is generally fixed in the constitution (Döring, 1995).

A set of rules and prerogatives have been created for the purpose of dealing with the scarcity of plenary time, which has allowed legislatures to move from a hypothetical "legislative state of nature" - where any member could speak and make motions without restrictions - into fully organised bodies. As pointed out by Cox (2006), two elements characterise the "plenary bottleneck". One is access to the debate agenda, which has to do with legislators' right to express their opinions in floor speeches (Proksch and Slapin, 2012). The other element that is to be regulated in order to avoid legislative gridlocks is access to the voting agenda - i.e. members' right to introduce legislative proposals. The voting agenda deals with the subset of bills or issues that reach the plenary and are then voted on. In this perspective, the ability to control the design and the selection of those proposals gaining access to the vote in the plenary sessions - the so-called agenda-setting prerogatives - represents a crucial source of power (Döring, 1995; Cox and McCubbins, 1993, 2005).

\section{Agenda selection in hard times: a research hypothesis}

The literature on policy agendas sheds light on the link between external shocks and changes in the level of attention among different policy issues, whilst studies of legislative organisation provide insights on how these changes are translated into the legislative agenda. Taken together, these two approaches help to evaluate the impact of external shocks on the policymaking process. In particular, the first strand of literature suggests that the parliament's agenda - i.e. the set of policy issues to which the parliament attends - emerges from the continuous political 
debate among political parties, which is institutionalised in regular legislative debates (GreenPedersen and Mortensen, 2010). ${ }^{2}$ The agenda is characterised by two attributes: space and diversity. "Space" denotes the maximum amount of attention available for policy issues in a given agenda and hence refers to the carrying capacity of a certain political decision-making actor or institution - in our case, the parliament. "Diversity" indicates instead how attention is allocated across all the issues composing the agenda at any one point in time. Exogenous shocks like economic downturns can have an impact on the distribution of attention, which can turn from being shared across a broad range of policy topics to being concentrated on a small set of issues (Jennings et al., 2011; Peter and De Vreese, 2003).

The second strand of literature casts light on how issues are processed by parliaments by focusing on the rules that regulate access to the agenda. Not all the legislative proposals that are introduced can be processed by parliament: since every hour devoted to a certain bill will reduce the time available for debating another one, parliament's decisions to debate a bill addressing some policy issue are made at the expense of proposals dealing with other domains. Time scarcity induces choices among bills and among the policy issues they address, which is also consistent with the concept of a finite agenda space emphasised by policy agendas scholars. ${ }^{3}$ Political actors make these decisions in legislative institutions such as committees and parliamentary directing authorities, which have been devised to overcome the "bottleneck" (Cox, 2006; Döring, 1995).

Generally, parliament's agenda is supposed to reflect parties' political priorities, which should be largely shaped by the policy program of the legislative coalition supporting the government (Froio, Bevan and Jennings, 2016). However, when a given policy issue - for example, protection of the environment - leaps to prominence due to some shocking events or external pressures - say, an environmental disaster or the lobbying activities of ecological groups - legislative proposals dealing with that domain will gain attention in the agenda of the 
parliament and will be probably selected for being discussed on the floor. This necessarily implies that the discussion of bills addressing other - less salient - policy issues will be postponed, and that some bills will not even reach the parliamentary floor. We expect that something similar will happen in times of dramatic economic crisis, when greater attention in the agenda of parliaments should be given to those bills including policy measures devised in order to deal with the worsening of economic conditions. Major shocks like economic crises usually receive considerable attention by the mass public and extensive media coverage, and this is likely to alter the agenda of political decision-makers within the parliament.

Our expectation rests on the premise that the current economic crisis acts as a major shock to a political system in a twofold way. First, as economic conditions worsen, higher attention should increasingly be given to crisis-related policy issues in the agenda of the parliament. Second, as time is an extremely scarce commodity in legislatures - or, equivalently, the agenda space of parliaments is finite - less and less room should be devoted to issues different from those related to the crisis. In other words, during the crisis the agenda of the parliament should increasingly concentrate on a few core issues related to the crisis, becoming less diverse. Since topics related to managing economic crises are reasonably those associated with public debt, national budget, inflation and taxation - that is, macroeconomic issues - we put forward the following hypothesis:

H1: In times of economic crisis, bills dealing with macroeconomic issues should become increasingly more likely to enter the parliamentary agenda. At the same time, as the crisis proceeds legislative proposals addressing other topics should become less likely to be discussed in the assembly.

\section{Italy and the economic crisis}


The economic fallout from the US financial crisis of 2008 rapidly acquired a global dimension. At the end of 2009 the economic crisis turned into a sovereign debt crisis in Europe, after the real size of the Greek budget deficit was made public. In the following three years markets increasingly lost confidence over the solvency of debt in several states, in particular in South European countries, which were characterized by structural weaknesses and bad reputation regarding their fiscal discipline. Greece (May 2010), Ireland (November 2010), Portugal (June 2011) and Spain (June 2012) signed up a bailout programme with the "Troika" (EU Commission, European Central Bank and International Monetary Fund). In exchange for financial assistance, the governments of these countries were forced to introduce severe austerity measures, such as labour markets and pensions reforms as well as cuts in public spending (Moschella 2017; Sacchi 2015).

Italy was sharply affected by the detrimental consequences of the economic crisis. Starting from the 2008-2009 period, the main economic indicators abruptly deteriorated (see Figure A1 in the Appendix). Particularly alarming was GDP decline, that made the economy enter recession. Moreover, in 2012 Italian public debt rose to 126.16 per cent of GDP - a figure considerably higher not only than the average value of the Eurozone, but also than the average value of South European member states. This was paralleled by mounting public concern about the situation of national economy, with a peak of negative evaluations - over 92 per cent of Italian citizens - in 2012 and 2013 (see Figure A2 in the Appendix).

Even though Italy did not formally sign up a bailout agreement, its credit ratings started being downgraded in the summer of 2011. This became a serious problem for the Italian government, a centre-right coalition led by Silvio Berlusconi (Berlusconi IV) and formed by the People of Freedom (PDL) party, the Northern League (LN) and other small groups. In a press conference held on 4 November 2011, Berlusconi minimised the impact of the crisis asserting that "consumptions of Italians have not decreased, restaurants are fully reserved and 
it is difficult to book a flight seat" (La Stampa, 5 November 2011). However, markets continued to withdraw their confidence in the Italian Prime Minister's (PM) capacity to steer his country's economy out of the crisis. Only five days after Berlusconi's incautious statement, the yield on Italian 10-year bonds dramatically soared over 7.6 per cent - a level that had previously forced Greece, Ireland and Portugal to seek a bailout from international institutions (see Figure 1). The negative trend of the main economic indicators, continuous pressures by financial markets, the EU and the International Monetary Fund, as well as the low cohesion of his legislative majority, forced Berlusconi to resign.

\section{[Figure 1 here]}

While other Southern European countries called snap elections after the incumbents' resignations, Italy followed a different path. Instead of dissolving the parliament, the President of the Republic appointed the former EU Commissioner and university professor Mario Monti to head a technocratic cabinet composed entirely of non-partisan ministers. The Monti government could rely on an unprecedented parliamentary support based on a broad and heterogeneous coalition. Together with the centre-right PDL, the legislative majority included the largest parties that had opposed the outgoing Berlusconi's government: the centre-left Democratic Party (PD) and the centrist Union of Christian Democrats (UDC).

As explicitly stated by the new PM in his investiture speech, the Monti's government was specifically committed to dealing with the crisis. Monti said that his government's policy agenda would have mainly focused on fiscal rigour, economic growth and fairness. He identified two primary goals for his government activity. In a first phase, to cope with the emergency generated by the financial crisis, ensure the sustainability of public finance and 
restore markets' confidence in the Italian economy. In a second phase, to restart economic growth and support Italian firms.

\section{Data and methods}

To empirically test our hypothesis concerning the parliamentary agenda in time of economic crisis, we used a new dataset covering all the bills that entered the committee stage in the Chamber of Deputies during Italian Legislature XVI (2008-2013). We checked for the robustness of our findings by analysing also data from a pre-crisis parliamentary term: Italian Legislature XIV (2001-2006). The two parliamentary terms share important aspects. In both cases, after the election a centre-right government formed, featuring Berlusconi as PM and a parliamentary majority including almost the same parties. ${ }^{4}$ Moreover, the two legislatures have an almost equal length, which allows reliable comparisons in the agenda dynamics. ${ }^{5}$

Before describing the data and methods employed to test our conjecture, it is worth briefly discussing how the legislative agenda is organised in the Italian parliament. In both chambers a steering committee composed of the chairpersons of all the parliamentary party groups - named Conference of Group Chairpersons (CGC) - is charged with arranging ex ante the long-term "program" of the plenary. Both in the Chamber and in the Senate, the CGC is convened by the President of the assembly and has the task of defining the list of topics that the parliament will debate, identifying policy priorities and the period in which they will be included in the order of the day of the assembly. Finally, detailed legislation to be debated enters short-term "calendars", which also include information on the amount of time to be allocated for the discussion of each bill proposal (Giannetti, Pinto and Pedrazzani 2016).

According to the Standing Orders of the Chamber, an agreement of chairpersons representing three-quarters of the members is needed in order to decide upon the parliamentary program. Failing that, it is up to the President of the Chamber to set the program of the plenary. 
In any case, government's priorities are taken into consideration by the CGC. Once decided by the CGC (or by the President), the legislative agenda cannot be amended by the assembly. When choosing which topics are to be given precedence, the CGC has to carefully consider the work of legislative committees, which in turn should take into account the policy priorities set by the CGC. Committees play a relevant role in filtering the huge amount of legislative proposals introduced to the legislature. Once assigned to a committee, most of the bills languish for the whole legislature without being actually examined. Others start discussion, entering the committee stage. Among these, some proposals successfully conclude committee examination and reach the floor to be debated and eventually voted, thus defining the parliamentary agenda.

Given that only the bills which start the committee stage have the possibility to enter the legislative agenda, we collected data on the entire population of ordinary, constitutional, and law-decree conversion bills examined by parliamentary committees in the legislatures under analysis. ${ }^{6}$ Overall, we included the 1,110 proposals which started examination in committee during Legislature XVI, and the 1,443 proposals which started being examined at the committee level during Legislature XIV. These figures correspond to about one-fourth of all the bills introduced during either legislature. If a bill reaches the floor to be debated, entering therefore the parliamentary agenda, our dependent variable (InAgenda) is coded as unity; it is coded zero otherwise. Of the total amount of bills that constitute our units of analysis, only about 31 per cent (in Legislature XVI) and 43 per cent (in Legislature XIV) passed the committee stage and reached the floor of the assembly to be debated. ${ }^{7}$

Due to the dichotomous nature of the dependent variable, we used a logistic regression model to assess whether bills dealing with macroeconomic issues become increasingly more likely to enter the parliamentary agenda in time of crisis. We tested this hypothesis against data from Italian Legislature XVI, and repeated the analysis using data from Legislature XIV. In both models, the latent variable InAgenda* measures the underlying propensity of bill proposals 
to enter the parliamentary agenda. InAgenda* is modelled using the following multiplicative interaction model:

$$
\begin{aligned}
\text { InAgenda } * & =\beta_{0}+\beta_{1} \text { Policy sector }+\beta_{2} \text { Time }+\beta_{3} \text { Policy sector X Time }+\beta_{4} \text { Bill Type } \\
& +\beta_{5} \text { Proposer }+\beta_{6} \text { Initiative }+\beta_{7} N . \text { Committee referrals } \\
& +\beta_{8} \text { Pre committee stage duration }+\beta_{9} \text { Government }+\varepsilon_{i} .
\end{aligned}
$$

Based on the hypothesis put forward, we modelled the likelihood that a bill will be included in the parliamentary agenda as a function of the interaction between its policy sector and time. The policy sector of bill proposals was coded according to the Italian Policy Agendas (IPA) codebook (Borghetto and Carammia, 2010), which has been developed within the Comparative Agendas Project (CAP). ${ }^{8}$ More precisely, we assigned each bill proposal to one of the 20 policy domains included in the IPA codebook. Since some domains have only few observations, we then aggregated the original 20 policy sectors into 10 working categories. Table 1 reports the distribution of bills across topics in both the legislatures included in our analysis. We computed also a dichotomous version of this variable, whose value is 1 for legislative proposals addressing macroeconomic topics - i.e. crisis-related bills - and 0 for bills dealing with other policy sectors. ${ }^{9}$

\section{[Table 1 here]}

Time corresponds to the number of days between the start of the legislature and the day in which a committee starts examining a bill proposal. This covariate tracks the period in which bills enter the committee stage, thus capturing the time effect of exogenous shocks on the definition of policy priorities. For example, bills that started being examined in committee 120 days after the onset of Legislature XVI entered this crucial phase of the legislative process in September 2008 - that is, at the beginning of the global crisis. In contrast, legislation that was 
considered by committee 1,200 days after the start of the legislature entered the committee stage in August 2011, when Italian credit ratings started to be sharply downgraded and citizens' negative evaluations of the economic situation approached 90 per cent.

Since the main economic indicators show a progressive deterioration as the end of Legislature XVI approaches (see above and the Appendix), time can be considered as a proxy of the worsening of the economic crisis. This variable does not only refer to the strictly macroeconomic dimension of the crisis; more in general, it is meant to measure also the negative impact of the crisis on public attitudes toward the national economic situation and discontent on key political actors. ${ }^{10}$ As a consequence, during Legislature XVI - i.e. in the course of the crisis - the interaction between policy sector and time should have impact on the likelihood that bills reach the floor debate as hypothesised in H1. However, this should not happen during pre-crisis Legislature XIV.

To properly single out the effects of our main covariates, we also considered a number of control variables that have been identified in previous literature as affecting the legislative process in Italy and other parliamentary countries (Capano and Giuliani, 2003; Giuliani, 2008; Pedrazzani and Zucchini, 2013). First, we included a set of variables that capture bill-specific characteristics: bill type, coding each proposal as an ordinary bill, a law-decree conversion or a constitutional act; proposer, controlling whether the promoter of the legislation belongs either to the majority or to the opposition, or whether the proposal has a consensual nature (i.e., the bill is cosponsored by members of both majority and opposition); initiative, checking if the bill proposal was initiated by a cabinet minister or by a member of the parliament. Second, we included in our analysis a measure of bill complexity: the number of committee referrals to which the bill was assigned. A particularly complex bill with a high number of committee referrals could experience a long examination process in the pre-floor stage, which will make that bill less likely to reach the floor and be debated by the assembly. Third, in order to control 
for the timing of bill introduction, we adopted a further covariate related to time (pre-committee stage duration), measuring the time elapsed between the day of bill introduction and the day in which the discussion at the committee level starts. A particularly long duration of the precommittee stage often indicates a rather low probability that a bill will enter the legislative agenda.

Finally, we incorporated the dummy government identifying the cabinet under which a bill was examined (Berlusconi IV and Monti for Legislature XVI, Berlusconi II and III for Legislature XIV). ${ }^{11}$ This variable was included to test whether a change in the Italian parliament's agenda is due simply to a government replacement during Legislature XVI. Monti's technocratic government was explicitly aimed at coping with the crisis. If any change in lawmaking patterns were found during Legislature XVI, it could then be contested that it was the alternation of two governments with different preferences during that legislative term - and not the combination of external pressures and time scarcity - to be responsible of the trends observed in the agenda. Descriptive statistics are provided in the Appendix (Table A1).

\section{Empirical results}

We empirically evaluated our main hypothesis against data from Italian Legislature XVI (20082013) by running two logistic regression models with robust standard errors. More precisely, Model 1 included a dichotomous version of the main independent variable identifying the policy content of legislation: as mentioned above, this variable is equal to 1 for bill proposals addressing macroeconomic topics and 0 otherwise. Model 2 incorporated instead a set of dummy indicators for policy sectors, with Macroeconomics as the omitted reference category. As mentioned above, we checked for the robustness of our findings by analysing data from precrisis Italian Legislature XIV (2001-2006). Also in this case we ran two logistic regression 
models, one with a dichotomous indicator for macroeconomic bills (Model 3) and one with a set of nine policy dummies (Model 4).

The inclusion of multiple interactions between policy sectors and the time in which bills enter the committee stage can make the interpretation of results difficult. Despite the interaction terms are all significant and in the expected direction, getting substantively meaningful interpretations is further complicated by the fact that the coefficients estimated from logistic regression relate to the latent propensity of entering the legislative agenda for different types of bills, rather than to their probability. For these reasons, we do not report the table of results (which is provided in Table A2 in the Appendix) but explicitly rely on a graphical inspection of the effect of our covariates on the probability of entering the parliamentary agenda for different types of bill proposals (Brambor, Clark and Golder, 2006).

The results displayed in Figures 2 and 3 support our expectation about the impact of the economic crisis on the agenda of the Italian parliament. As the crisis proceeds during Legislature XVI, the parliament's agenda tends to become more and more focused on macroeconomic issues, at the expense of other topics unrelated to the crisis. As indicated by the solid black line in Figure 2 (which is based on Model 1), soon after the start of Legislature XVI bills addressing macroeconomics have a probability of entering the parliament's agenda of 31 per cent - that is, less than one over three macroeconomic bills are expected to be selected for debate on the floor. ${ }^{12}$ Over time, however, dealing with macroeconomic issues constantly increases proposals' likelihood of terminating the pre-floor stage and reaching the debate agenda of parliament, which is consistent with the first part of our hypothesis. When the Greek debt rating is downgraded in May 2010 - i.e. about 730 days after the start of the legislature the chance of entering the parliament's agenda is 50 per cent for a bill dealing with crisis-related matters. This probability keeps on rising with the worsening of the Eurozone crisis, and exceeds 65 per cent after the peak of the Italian spread in November 2011, when the percentage of Italian 
citizens expressing a negative evaluation of the national economy becomes greater than 90 per cent. Put it differently, two macroeconomic bills over three get access to the floor during Monti's government. Conversely, as expected in the second part of our hypothesis, the probability of being selected for parliamentary discussion decreases over time for bills about topics other than macroeconomics (grey solid line). While at the beginning of Legislature XVI bills unrelated to the crisis have a probability of about 50 per cent to enter the parliament's agenda, two years later the same probability becomes 31 per cent and finally shrinks to less than 20 per cent during the last year of the parliamentary term.

\section{[Figure 2 here]}

\section{[Figure 3 here]}

Evidence of the progressive impact of the economic crisis on the parliamentary process in Italy is found also in Figure 3, where the category of bills unrelated to macroeconomic issues is disaggregated into nine policy domains (Model 2). The picture displays over time the difference between the probability that various types of bills - say, a bill about immigration enter the parliamentary agenda and the probability that crisis-related legislation - that is, macroeconomic bills - enters the parliamentary agenda. In each of the nine plots, a positive predicted difference means that bills in a specific policy domain are more likely to be selected than macroeconomic proposals, while a negative difference indicates that macroeconomic bills are more likely to enter the legislative agenda.

Overall, all the nine plots show the same trend: macroeconomic legislation becomes increasingly more likely to enter the parliament's agenda than other types of bills. At the beginning of Legislature XVI, macroeconomic proposals do not have a significantly greater probability of being selected vis-à-vis other types of bills, as the confidence intervals estimated 
around the predicted difference cross the zero line in almost all the cases. Let us note that legislation in two policy domains - business and immigration - is actually more likely than macroeconomic bills to be prioritised by the Italian parliament at the beginning of Legislature XVI. This may reflect the particular attention given to these topics by the centre-right government led by Berlusconi. Later on, all topics become increasingly less likely to enter the floor agenda than macroeconomic, crisis-related legislation. The first bills to be displaced by macroeconomic legislation in the agenda of the Italian parliament are those dealing with environment, defence, and education and culture. The last are those about immigration and business, which are displaced by macroeconomic bills just in the last part of the legislature. Towards the end of the legislature, all other bills are about 50 per cent less likely to get access to the parliament's agenda compared to macroeconomic legislation.

Of course, not all crisis-related bills are the same. Although during Legislature XVI macroeconomic legislation was increasingly intended to respond to the economic shock, different types of bills addressed distinct aspects of the crisis. An analysis of the different macroeconomic bills that entered the agenda of the Italian parliament during Legislature XVI allows then to understand how the allocation of political attention has evolved over time across specific topics within the macroeconomic domain. To this purpose, we classified the 42 macroeconomic bills entering the floor agenda in the 2008-2013 period according to the minor categories of the CAP/IPA scheme. About 24 per cent of these bills are related to the annual Community Act and hence are evenly distributed throughout the parliamentary term. The rest of macroeconomic bills follow instead more specific patterns, revealing how the policy strategies undertaken to tackle the crisis have changed over time. Of these bills, in particular, roughly one-fifth implemented measures of domestic industrial policy (e.g. industrial revitalisation and reorganisation, support to industrial growth) and another fifth dealt with fiscal policies (tax reduction and tax code simplification). Bills addressing these two topics entered 
the agenda especially under Berlusconi IV government. In contrast, roughly 20 per cent of the macroeconomic bills were associated with national budget and debt and started entering the parliamentary agenda in November 2011, after Monti was appointed Prime Minister.

As Figure 4 shows, the comparison with Italian Legislature XIV corroborates our general results. During a parliamentary term that ended before the economic crisis and hence was not affected by such an external shock, the data on agenda formation in the Italian parliament are not consistent with $\mathrm{H} 1$. The dynamics of parliamentary agenda formation throughout pre-crisis Legislature XIV are quite different from those characterising Legislature XVI. ${ }^{13}$ In the 2001-2006 period we do not observe any increase in the attention given to macroeconomic topics; on the contrary, at the beginning of Legislature XIV macroeconomic bills have a probability of entering the parliament's agenda of 44 per cent and afterwards this probability decreases, reaching 27 per cent at the end of the term. The same happens to legislation dealing with other topics, whose chance of being selected for floor debate lowers from 58 to 24 per cent during the term. As the parliamentary term proceeds, the time available for debate shrinks and hence all types of bill proposals become less and less likely to be chosen for being discussed on the floor. ${ }^{14}$

[Figure 4 here]

As for the control variables included in the models, let us underline that bills' propensity to enter in the legislative agenda results to be unrelated to the alternation of two different cabinets during Legislature XVI. The dummy indicating government change is not statistically significant in Legislature XVI (and so does in Legislature XIV).${ }^{15}$ Together with the results reported by Figures 1 and 2, which show that the attention towards economic policies started 
rising when Berlusconi was still in power, this finding gives further support to the "external pressure" argument.

In comparison with ordinary proposals, law-decree conversion bills are four times more likely to enter the legislative agenda during Legislature XIV, and as many as 20 times during Legislature XVI. This comes as no surprise, since law-decrees are one of the most powerful instruments used by Italian governments to circumvent the parliament in order to speed up the legislative process, push their own agenda and respond to external shocks (Capano and Giuliani, 2003). In turn, in both legislatures the probability of entering the parliamentary agenda for bills initiated by MPs is one-seventh of the chance that government proposals have. Similarly, a higher number of committees examining a bill slows down the pre-floor stage reducing its probability to be debated in the assembly: one more committee referral lowers by 2 per cent this probability. Finally, the longer the pre-committee stage, the lower is bills' propensity to enter the parliamentary agenda. Bills that languish for a long time before being discussed by the committee are seldom selected for being debated on the floor.

\section{Conclusions}

Much has been written about the economic and social fallout of the financial crisis that has recently hit EU member states. A growing scholarship is exploring the repercussions of the Eurozone crisis on political phenomena such as electoral behaviour, citizens' confidence in national and EU institutions, elected representatives' activities, and policy outcomes. Focusing on an important aspect neglected by the literature, this paper instead examines the role played by the crisis in shaping domestic policymaking processes. More precisely, we investigated if and how the challenges produced by the negative economic juncture affected a crucial phase of the lawmaking process: the definition of the legislative agenda. 
Relying on the existing contributions on policy agendas and parliamentary processes, we hypothesised that with the worsening of the crisis law proposals dealing with macroeconomic issues become increasingly more likely to enter the legislative agenda displacing bills addressing other topics. Empirical results confirmed our conjecture: as the crisis worsened in the $2008-2013$ period, bills related to macroeconomic issues had more chances to enter the Italian parliament's agenda, whereas law proposals dealing with other topics became less and less likely to be debated by the assembly. The comparison with a pre-crisis parliamentary term strengthened our findings: when severe exogenous shocks were absent, we did not observe any relevant difference between policy sectors in the probability to enter the legislative agenda throughout the legislative term.

Our data support therefore the notion that exogenous shocks such as the Eurozone crisis affect not only countries' economic performances, but also the policymaking process of representative democracies, and in particular the definition of the legislative agenda. The sovereign debt crisis altered the policy priorities of the key political actors in Italy's government and parliament, thus redefining the traits of law production and the output of the political system. While limiting the space in the agenda for other policy issues, the Italian parliament devoted its attention mainly to those bills aiming to face the crisis by enacting the austerity measures promoted at the EU level. Importantly, our analyses also show that the re-definition of the parliamentary agenda was not directly attributable to the replacement of the apparently “irresponsible" Berlusconi's cabinet with a technocratic cabinet. Under the two governments, however, the Italian parliament's attention was differently prioritised across specific macroeconomic topics. In the first part of Legislature XVI, precedence was given to bills supporting industrial growth and to attempts to prevent reduction of citizens' consumption through tax reforms. Later, measures intended to contain budget deficit and debt were highly prioritised. 
The skewed distribution of legislative attention in favour of macroeconomic policies at the expense of other topics can have important implications for the process of representation. Insofar as democratic representation hinges upon parties as a crucial link between society and political institutions, abrupt shifts in the allocation of attention can be detrimental to the "regular" cycle of representation and accountability. Parties are ordinarily expected to propose alternative policy packages to citizens and, in case they win the national elections, are supposed to try to implement those programs; in the next election, voters can then punish or reward the incumbent parties. When some external shock suddenly forces a country's parliament and government to shrink their political agenda, parties' capacity to translate citizens' preferences into programmes and policies is undermined, and elections may be weakened as an accountability mechanism.

What emerges from our analysis is that, starting from 2010, the "crisis management" monopolised the parliamentary agenda, leaving almost no space for other manoeuvres. The inability of the parliament to enact measures other than economic policies prompted the Italian President of the Republic Giorgio Napolitano to describe Legislature XVI as another "wasted legislature" (Corriere della sera, 17 December 2012). The policies conceived to tackle the crisis were undoubtedly done in the interest of Italian citizens - who, as we reported above, were worried about the bad economic situation. However, the almost complete underestimation of other priorities, together with the scarce results in boosting the Italian economy obtained by the measures approved during Legislature XVI, probably help to explain the poor performance of all the parties that had supported the technocratic government (including a new party lead by Monti himself) in the 2013 general elections.

Future studies testing the hypothesis advanced above in a comparative perspective would be particularly interesting. The replacement of the "regular" political agenda of national parliaments with a common crisis-related agenda might indicate the spread of a sort of 
"legislative" epidemic across Europe. Italy could be fruitfully compared with other European democracies that have been less extensively hit by the negative fallouts of the economic crisis in order to assess potential differences in the policymaking processes. The Italian case could be also compared with the other South European democracies, where economic distress was more acute. It would be particularly intriguing to compare Italy with countries that experienced a technocratic executive such as Greece. In addition to cross-country comparisons, our study could be extended diachronically to assess whether the policymaking patterns emerging in Italian Legislature XVI are persistent or not. The crisis could have established new lawmaking dynamics centred upon macroeconomic issues, according to a logic of "path dependency". 


\section{Endnotes}

${ }^{1}$ Policy "punctuations" can be thought of as similar to earthquakes or landslides. They can be precipitated either by a major shock that simply cannot be ignored, or by a series of minor events that add up over longer periods of time (Baumgartner and Jones, 1993).

${ }^{2}$ The parliament's agenda - that Green-Pedersen and Mortensen (2010) call "party-system agenda" - plays a twofold role. On the one hand, it acts as a constraint because individual parties must address the issues that are prominent on the agenda. On the other hand, parties compete to influence the future content of the agenda.

${ }^{3}$ Legislative committees allow the parallel processing of multiple issues according to a division of the parliamentary labour. However, the system of committees is not infinitely expandable and the legislature as a whole has a finite carrying capacity.

${ }^{4}$ In addition to the UDC, the legislative majority supporting Berlusconi's cabinet after the 2001 election (Berlusconi II) comprised Forward Italy, National Alliance (two parties that later merged into the PDL) and the LN. As a result of a cabinet reshuffle, in April 2005 the same parties supported the formation of government Berlusconi III.

${ }^{5}$ We did not take Legislature XV (2006-2008) as a term of comparison because this lasted no more than two years.

${ }^{6}$ Law-decrees are decrees promulgated by the government with immediate force of law. According to the Italian constitution, in the same day in which the decree is emanated the government must introduce a law proposal that aims to convert the decree into law. If this bill is not approved by the parliament in 60 days, the related law-decree loses its effects.

${ }^{7}$ Following a standard practice in studies of the legislative process in Italy, we did not consider bills ratifying international treaties. The few EU-related bills concerning public debt and national budget are included in the Macroeconomics category (see below). Excluding these bills 
does not change our results. We also excluded from the dataset budgetary bills, which are adopted with special procedures and always enter the parliamentary agenda.

${ }^{8}$ For further information on the CAP see: http://www.comparativeagendas.org. For the IPA see: http://italianpolicyagendas.weebly.com/.

${ }^{9}$ Examples of macroeconomic bills are C1301/2001 "Delegation to the government to develop a tax on speculative financial transaction from and to foreign countries" and C4843/2011 "Regulations to public debt reduction and the promotion of economic investments and development through the public real estate sale".

${ }^{10}$ For simplicity, we assume that the impact of our crisis-related variable (time) is linear. Using a different function of the time (logarithmic or quadratic) does not affect our findings.

11 All the information on bills was taken from the website of the Italian Chamber (http://dati.camera.it).

${ }^{12}$ Let us also note that at the beginning of the parliamentary term the policy content of a bill does not influence its probability of entering the assembly's agenda: the likelihood of being chosen for floor debate is not statistically significant different between macroeconomic bills and other types of legislation.

${ }^{13}$ If patterns of parliamentary agenda formation in Legislature XIV were similar to those observed during Legislature XVI, then the latter could not be explained by the pressures related to the worsening of the economic crisis. In other words, the increasing attention devoted to macroeconomic topics at the expense of other policy issues would be an "ordinary" phenomenon in the course of parliamentary terms, independent of exogenous shocks.

${ }^{14}$ This clearly implies that, unlike what we found about Legislature XVI, during Legislature XIV macroeconomic legislation does not displace other types of bills over time. The fact that, during Legislature XIV, many types of non-macroeconomic bills have decreasing chances of entering floor debate is not necessarily inconsistent with the second part of our hypothesis: the 
probability that bills unrelated to macroeconomics enter the parliament's agenda drops more quickly during Legislature XVI (when a sort of "displacement" effect is in place along with the progressive reduction of the overall time available for discussion) than during Legislature XIV. See Figure A3 in the Appendix for the difference in predicted probabilities of entering the legislative agenda for different types of bills during Legislature XIV.

${ }^{15}$ We further explored the possible impact of government-related factors by employing two strategies. First, we ran two separate models, one for each of the governments that served during Legislature XVI (Berlusconi IV and Monti). In either case, the interaction between macroeconomic policy and time is significant and consistent with our expectations. Second, we included an interaction between the government dummy and the dummy addressing macroeconomic topics, instead of the interaction between the latter and time. The coefficient on the interaction between government and macroeconomic policy is not statistically significant (data available upon request). All together, these results indicate that our findings are robust to alternative arguments related to government composition and the content of the agenda. 


\section{References}

Alexandrova, P., M. Carammia, and A. Timmermans (2012). 'Policy Punctuations and Issue Diversity on the European Council Agenda', Policy Studies Journal, 40(1): 69-88.

Baumgartner, F.R. and B.D. Jones (1993). Agendas and Instability in American Politics. Chicago, IL: University of Chicago Press.

Baumgartner, F.R. (2001). 'Political Agendas'; in N.J. Smelser and P.B. Baltes (eds.), International Encyclopedia of Social and Behavioral Sciences: Political Science. New York: Elsevier Science Publishers, 288-90.

Blumenau, J., and B.E. Lauderdale (2017). 'Never Let a Good Crisis Go to Waste: Agenda Setting and Legislative Voting in Response to the EU crisis', Journal of Politics, forthcoming.

Borghetto, E. and M. Carammia (2010). 'L'Analisi Comparata delle Agende Politiche: Il Comparative Agendas Project', Rivista Italiana di Scienza Politica, 40(2): 301-315.

Borghetto, E. and M. Carammia (2015). 'The Influence of Coalition Parties on Executive Agendas in Italy (1983-2008)', in N. Conti and F. Marangoni (eds.), The Challenge of Coalition Government: The Italian Case. Abingdon: Routledge, 36-57.

Bosco, A. and S. Verney (2012). 'Electoral Epidemic: The Political Cost of Economic Crisis in Southern Europe, 2010-11', South European Society and Politics, 17(2): 129-154.

Bosco, A. and S. Verney. (2016). 'From Electoral Epidemic to Government Epidemic: The Next Level of the Crisis in Southern Europe', South European Society and Politics, 21(4): $383-406$.

Brambor, T., W.R. Clark and M. Golder (2006). 'Understanding Interaction Models: Improving Empirical Analyses', Political Analysis, 14(1): 63-82.

Capano, G., and Giuliani, M. (2003). 'The Italian Parliament: In Search of a New Role?', The Journal of Legislative Studies, 9(2): 8-34. 
Collier, R.B. and D. Collier (2002). Shaping the political arena. Notre Dame, IN: University of Notre Dame Press.

Cox, G.W. (2006). 'The Organization of Democratic Legislatures', in B.G. Weingast and D.A. Wittman (eds.) The Oxford Handbook of Political Economy. Oxford: Oxford University Press, 141-161.

Cox, G.W. and M.D. McCubbins (1993). Legislative Leviathan: Party Government in the House. Berkeley, CA: University of California Press.

Cox, G.W. and M.D. McCubbins (2005). Setting the Agenda. Cambridge, UK: Cambridge University Press.

Döring, H. (1995). 'Time as a Scarce Resource: Government Control of the Agenda', in H. Döring (ed.) Parliaments and Majority Rule in Western Europe. Frankfurt a. M. and New York: Campus, 223-246.

Froio, C., S. Bevan and W. Jennings (2016). 'Party Mandates and the Politics of Attention', Party Politics, forthcoming.

Garrett, G. (1998). 'Global Markets and National Politics: Collision Course or Virtuous Circle?', International Organization, 52(4): 787-824.

Giannetti, D., L. Pinto and A. Pedrazzani (2016). 'Setting Parliamentary Calendars: How Parties Allocate Time for Plenary Debates on Bills', Political Studies, 64(4): 1016-1035. Giuliani, M. (2008). 'Patterns of Consensual Law-making in the Italian Parliament', South European Society \& Politics, 13(1): 61-85.

Green-Pedersen, C. and S. Walgrave eds. (2014). Agenda Setting, Policies, and Political Systems: A Comparative Approach. Chicago; London: Chicago University Press.

Green-Pedersen, C., and P.B. Mortensen (2010). 'Who Sets the Agenda and Who Responds to It in the Danish Parliament? A New Model of Issue Competition and Agenda-Setting', European Journal of Political Research, 49(2): 257-281. 
Jennings, W., S. Bevan, A. Timmermans, G. Breeman, S. Brouard, L. Chaqués-Bonafont, C. Green-Pedersen, P. John, P.B. Mortensen and A.M. Palau (2011). 'Effects of the Core Functions of Government on the Diversity of Executive Agendas', Comparative Political Studies, 44(8): 1001-1030.

Jones, B.D., and F.R. Baumgartner (2005). The Politics of attention: How government prioritizes problems. Chicago, IL: University of Chicago Press.

Keeler, J.T. (1993). 'Opening the Window for Reform Mandates, Crises, and Extraordinary Policy-making, Comparative Political Studies, 25(4): 433-486.

Kingdon, J.W. (1984). Agendas, Alternatives and Public Policies. Boston: Little, Brown and Company.

Lindvall, J. (2014). 'The Electoral Consequences of Two Great Crises', European Journal of Political Research, 53(4): 747-765.

Morlino, L., and M. Quaranta (2016). 'What Is the Impact of the Economic Crisis on Democracy? Evidence from Europe', International Political Science Review, 37(5): 618633.

Moschella, M. (2017). 'Italy and the Fiscal Compact: Why Does a Country Commit to Permanent Austerity?', Italian Political Science Review, 47(2), 205-225.

Moury, C., and E. De Giorgi (2015). 'Introduction: Conflict and Consensus in Parliament during the Economic Crisis', The Journal of Legislative Studies, 21(1): 1-13.

Pedrazzani, A. and F. Zucchini (2013). 'Horses and Hippos: Why Italian Government Bills Change in the Legislative Arena (1987-2006)', European Journal of Political Research, 52(5): 687-714.

Peter, J., and C.H. De Vreese (2003). 'Agenda-rich, Agenda-poor: A Cross-national Comparative Investigation of Nominal and Thematic Public Agenda Diversity', International Journal of Public Opinion Research, 15: 44-64. 
Pierson, P. (2000). 'Increasing Returns, Path Dependence, and the Study of Politics', American Political Science Review, 94(2): 251-267.

Proksch, S.-O., and J.B. Slapin (2012). 'Institutional Foundations of Legislative Speech', American Journal of Political Science, 56(3): 520-537.

Sacchi, S. (2015). 'Conditionality by Other Means: EU Involvement in Italy's Structural Reforms in the Sovereign Debt Crisis', Comparative European Politics, 13(1): 77-92.

Sacchi, S., Pancaldi, F., and Arisi, C. (2011). 'The Economic Crisis as a Trigger of Convergence? Short-Time Work in Italy, Germany and Austria', Social Policy and Administration, 45(4): 465-487.

Singer, M.M. (2013). 'The Global Economic Crisis and Domestic Political Agendas, Electoral Studies, 32(3): 404-410.

Thelen, K (2004). How institutions evolve: The political economy of skills in Germany, Britain, the United States, and Japan. Cambridge, UK: Cambridge University Press. 
Tables and Figures

TABLE 1

CODING OF BILLS AND CLASSIFICATION BY POLICY SECTORS, ITALY 2008-2013 AND 2001-2006

\begin{tabular}{|c|c|c|c|c|c|}
\hline \multirow[t]{2}{*}{ Policy Sector } & \multirow[t]{2}{*}{ IPA codebook } & \multicolumn{2}{|c|}{ Legislature XVI } & \multicolumn{2}{|c|}{ Legislature XIV } \\
\hline & & $\begin{array}{c}\mathrm{N} . \\
\text { Bills }\end{array}$ & $\begin{array}{l}\text { Per cent } \\
\text { Bills }\end{array}$ & $\begin{array}{c}\mathrm{N} . \\
\text { Bills }\end{array}$ & $\begin{array}{c}\text { Per cent } \\
\text { Bills }\end{array}$ \\
\hline Macroeconomics & $\begin{array}{c}\text { Domestic Macroeconomic Issues; } \\
\text { EU related issues }\end{array}$ & 63 & 5.68 & 45 & 3.12 \\
\hline Social Welfare & $\begin{array}{l}\text { Health, Labour and Employment; } \\
\text { Social Welfare }\end{array}$ & 231 & 20.81 & 211 & 14.62 \\
\hline Law and Crime & Law, Crime, and Family Issues & 148 & 13.33 & 243 & 16.84 \\
\hline Government Operations & Government Operations & 173 & 15.59 & 203 & 14.07 \\
\hline Business Promotion and Regulation & $\begin{array}{l}\text { Community Development and } \\
\text { Housing Issues; Banking, Finance, } \\
\text { and Domestic Commerce } \\
\text { Agriculture; Environment; Energy; }\end{array}$ & 73 & 6.58 & 154 & 10.67 \\
\hline Environment & $\begin{array}{l}\text { Public Lands, Water Management, } \\
\text { and Territorial Issues }\end{array}$ & 134 & 12.07 & 160 & 11.09 \\
\hline Education and Culture & $\begin{array}{c}\text { Education; Space, Science, } \\
\text { Technology, and Communications; } \\
\text { Cultural Policy Issues }\end{array}$ & 72 & 6.49 & 184 & 12.75 \\
\hline Foreign affairs and Defence & $\begin{array}{c}\text { Defence; Foreign Trade; } \\
\text { International Affairs and Foreign } \\
\text { Aid }\end{array}$ & 92 & 8.29 & 92 & 6.38 \\
\hline Immigration and Civil Rights & $\begin{array}{c}\text { Civil Rights, Minority Issues, and } \\
\text { Civil Liberties; Immigration and } \\
\text { Refugee Issues }\end{array}$ & 46 & 4.14 & 76 & 5.27 \\
\hline Transportation & Transportation & 78 & 7.03 & 75 & 5.20 \\
\hline Total & & 1,110 & 100.00 & 1,443 & 100.00 \\
\hline
\end{tabular}


FIGURE 1

DIFFERENCE BETWEEN YIELD (PER CENT) OF 10 YEARS ITALIAN BONDS AND GERMAN BONDS

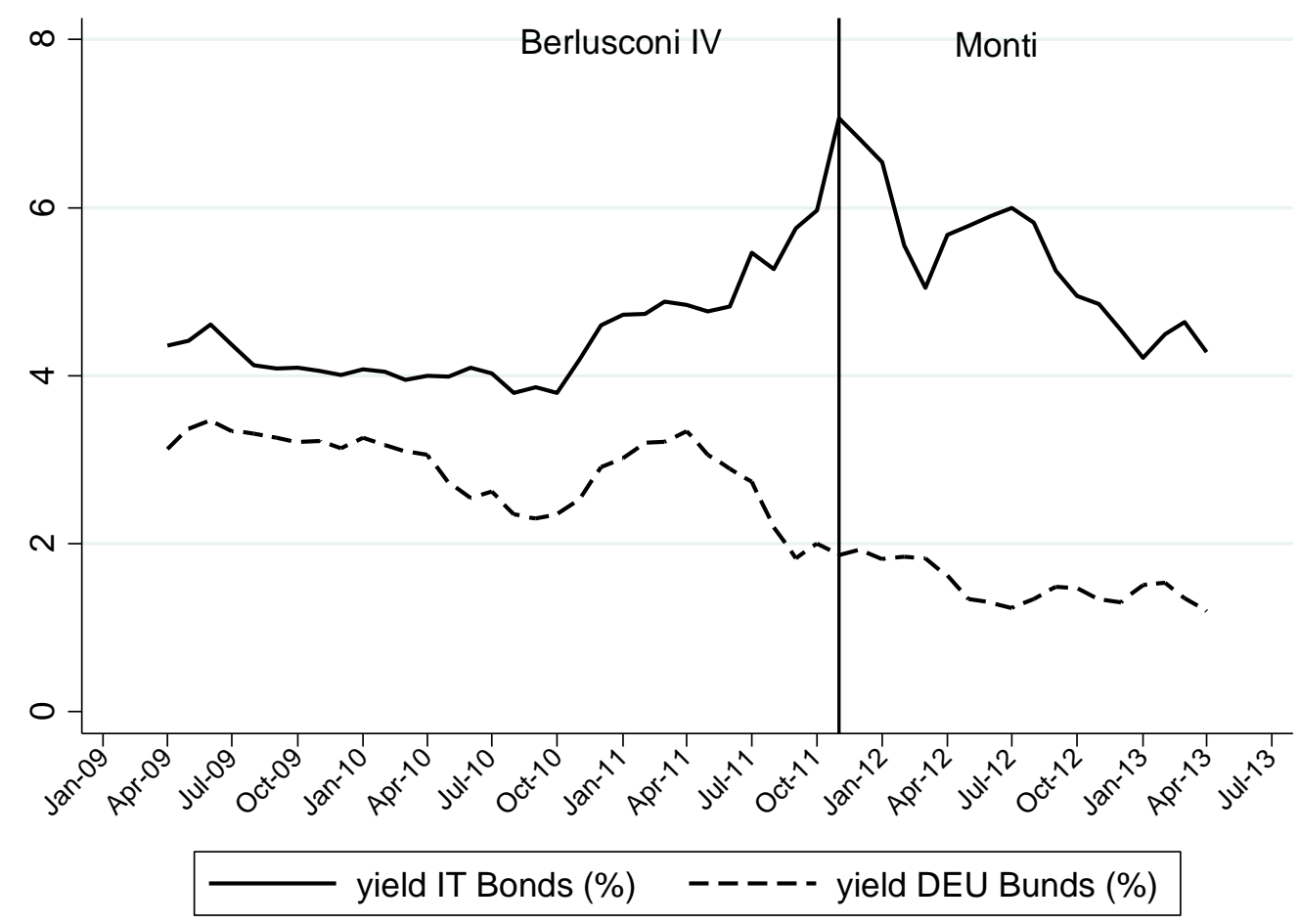

Source: European Central Bank (http://sdw.ecb.europa.eu/browse.do?node=bbn4864) 
FIGURE 2

PREDICTED PROBABILITY OF ENTERING THE LEGISLATIVE AGENDA FOR DIFFERENT TYPES OF BILLS (95 PER CENT CIs). MACROECONOMIC BILLS VS. OTHER POLICY SECTORS (LEGISLATURE XVI)

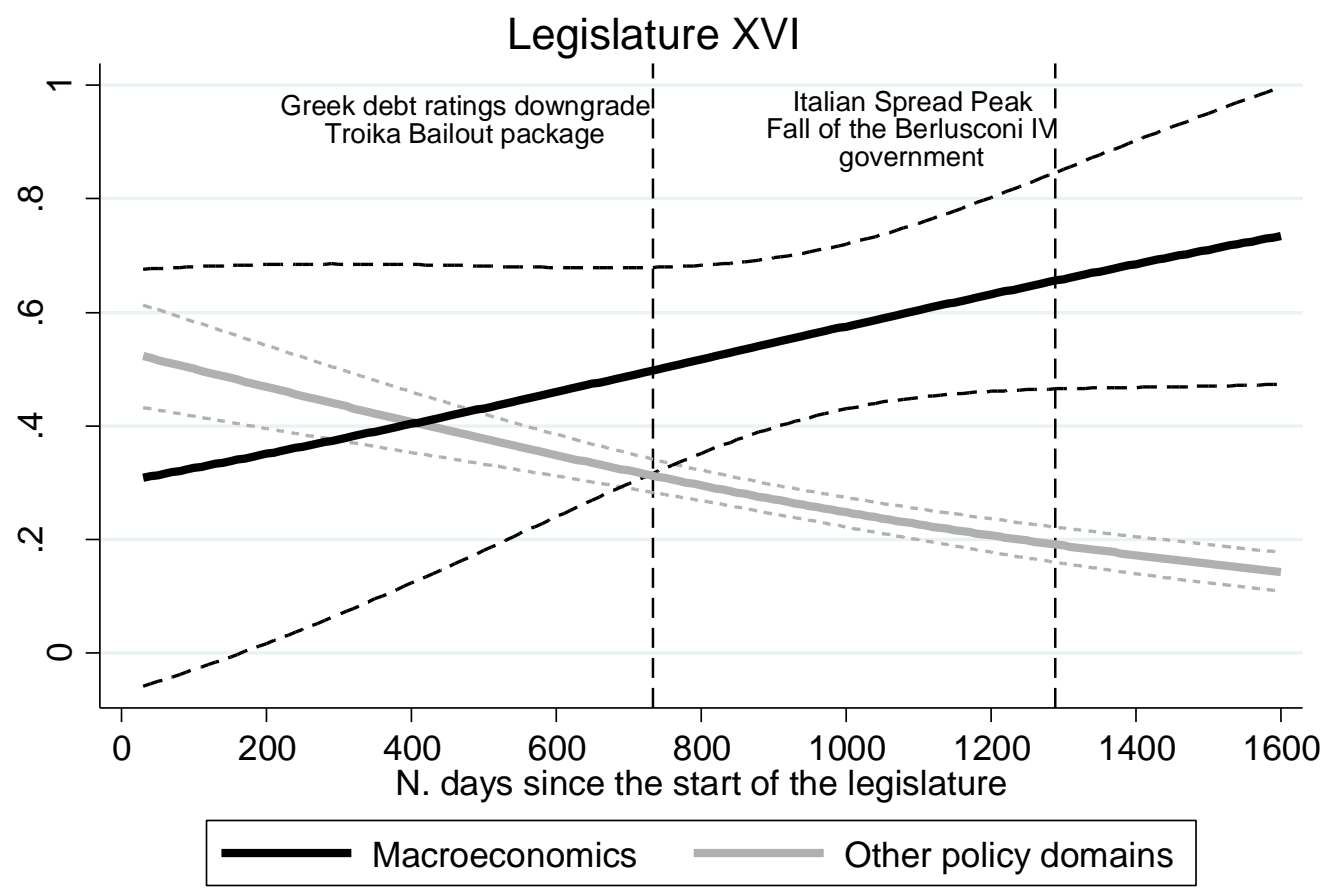

Notes: Estimates based on results of Model 1 (see Appendix) 
FIGURE 3

DIFFERENCE IN PREDICTED PROBABILITIES OF ENTERING THE LEGISLATIVE AGENDA FOR DIFFERENT POLICY SECTORS VS. MACROECONOMIC BILLS (LEGISLATURE XVI, 95 PER CENT CIs)

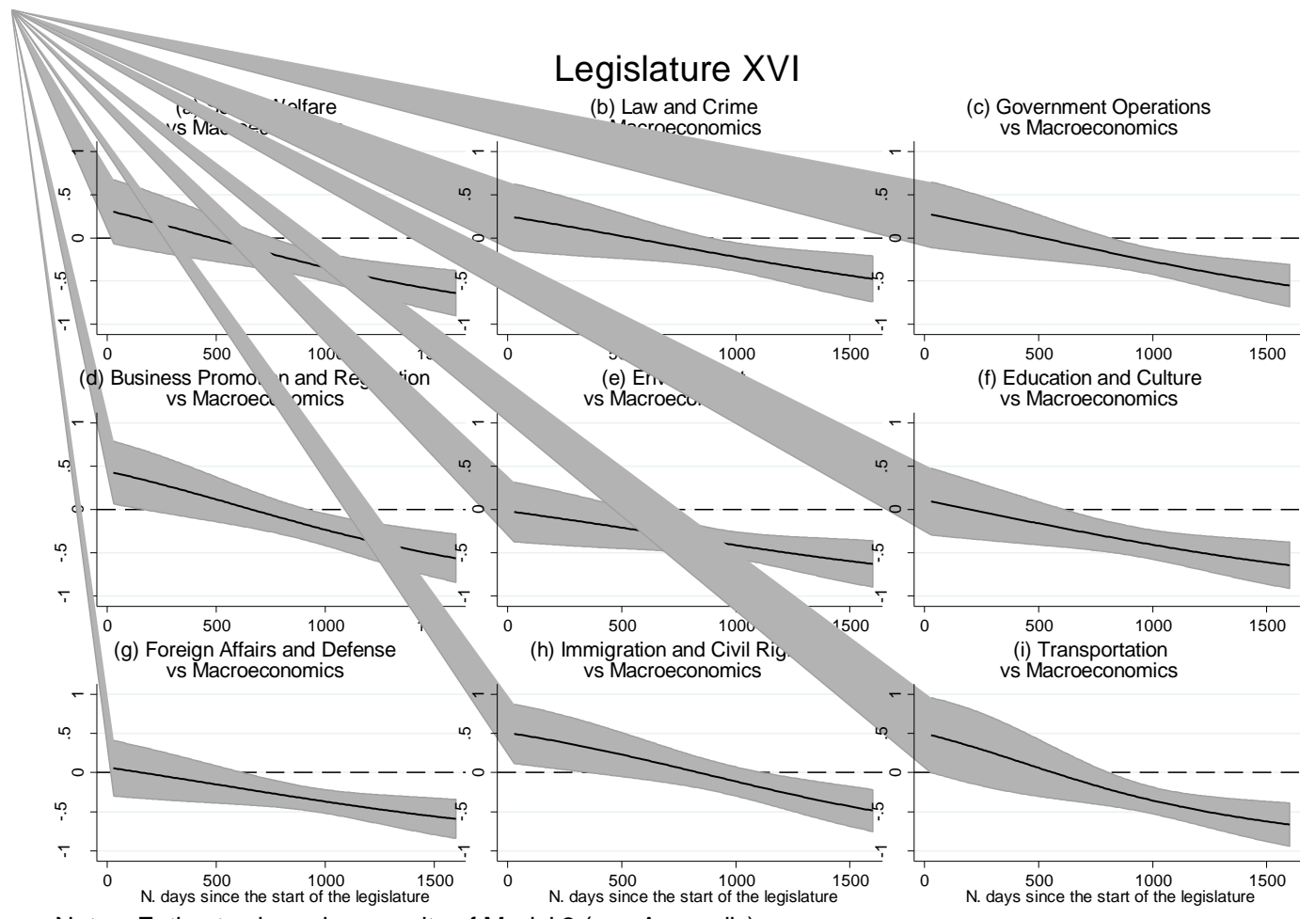
Notes: Estimates based on results of Model 2 (see Appendix). 
FIGURE 4

PREDICTED PROBABILITY OF ENTERING THE LEGISLATIVE AGENDA FOR DIFFERENT TYPES OF BILLS (95 PER CENT CIs). MACROECONOMIC BILLS VS. OTHER POLICY SECTORS (LEGISLATURE XIV)

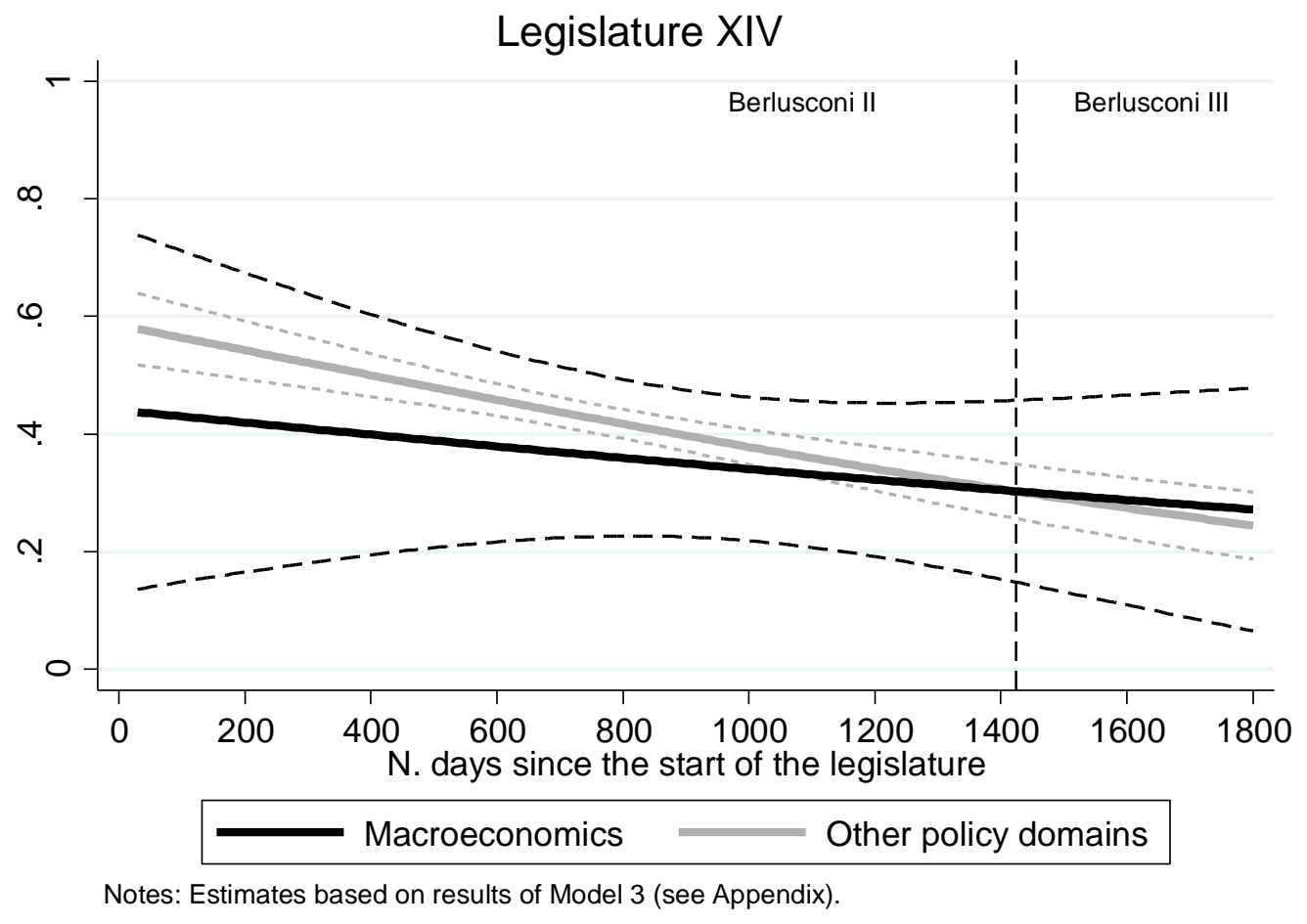


FIGURE A1

THE EFFECTS OF THE ECONOMIC CRISIS IN ITALY
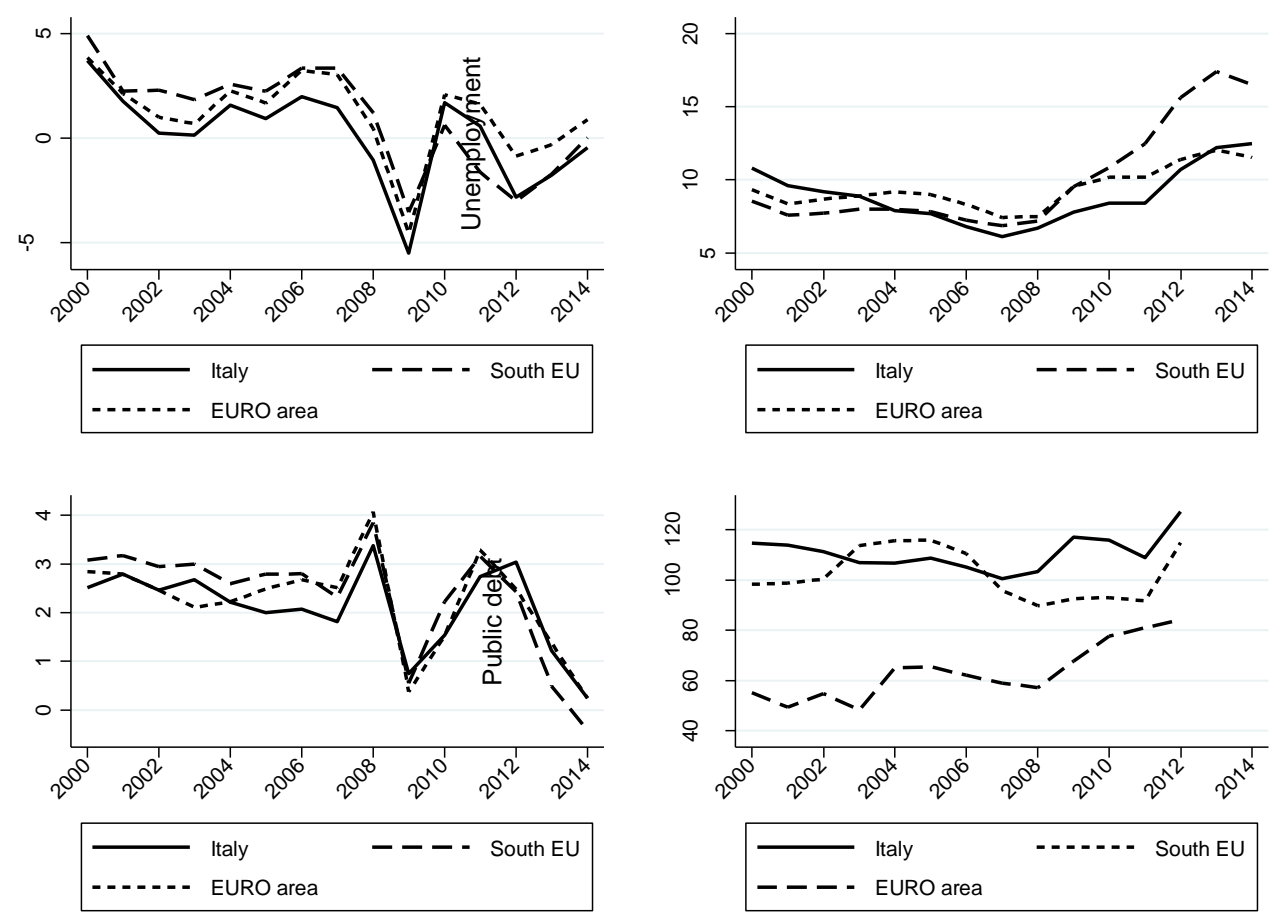

Notes: GDP growth is annual percentage growth rate of GDP at market prices based on constant local currency. Unemployment rate refers to the share of the labour force that is without work but available for and seeking employment. Inflation is measured by the consumer price index which reflects the annual percentage change in the cost to the average consumer of acquiring a basket of goods and services that may be fixed or changed at specified intervals, such as yearly. Public debt is measured as a percentage of the GDP. Values for South EU are the average values of the economic indicators in Cyprus, Greece, Italy, Malta, Portugal and Spain. Values for Euro area are the average values of the economic indicators in EU member states adopting EURO currency.

Source: World Development Indicators (http://data.worldbank.org/data-catalog/world-development-indicators). 
FIGURE A2.

ITALIANS' EVALUATION OF THE SITUATION OF THE NATIONAL ECONOMY, 2008-2013.

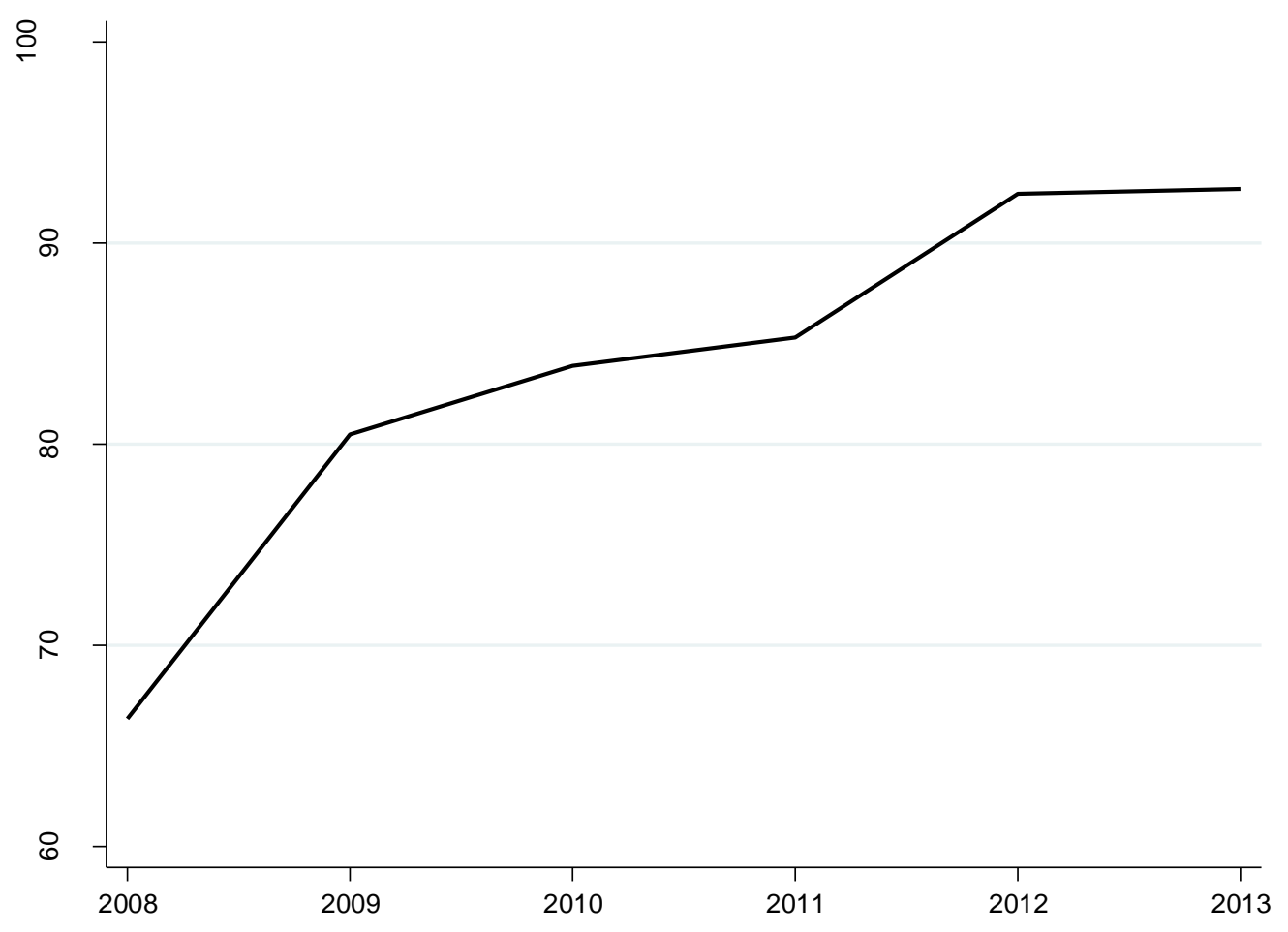

Notes: The question used is the following: How would you judge the current situation in each of the following? a) The situation of the (NATIONALITY) economy. The line represents the proportion of Italian respondents who answered "Rather bad" or "Very bad".

Source: Eurobarometer 2008-2013 (http://ec.europa.eu/COMMFrontOffice/PublicOpinion/). 
FIGURE A3

DIFFERENCE IN PREDICTED PROBABILITIES OF ENTERING THE LEGISLATIVE AGENDA FOR DIFFERENT TYPES OF BILLS (LEGISLATURE XIV, 95 PER CENT CIs)

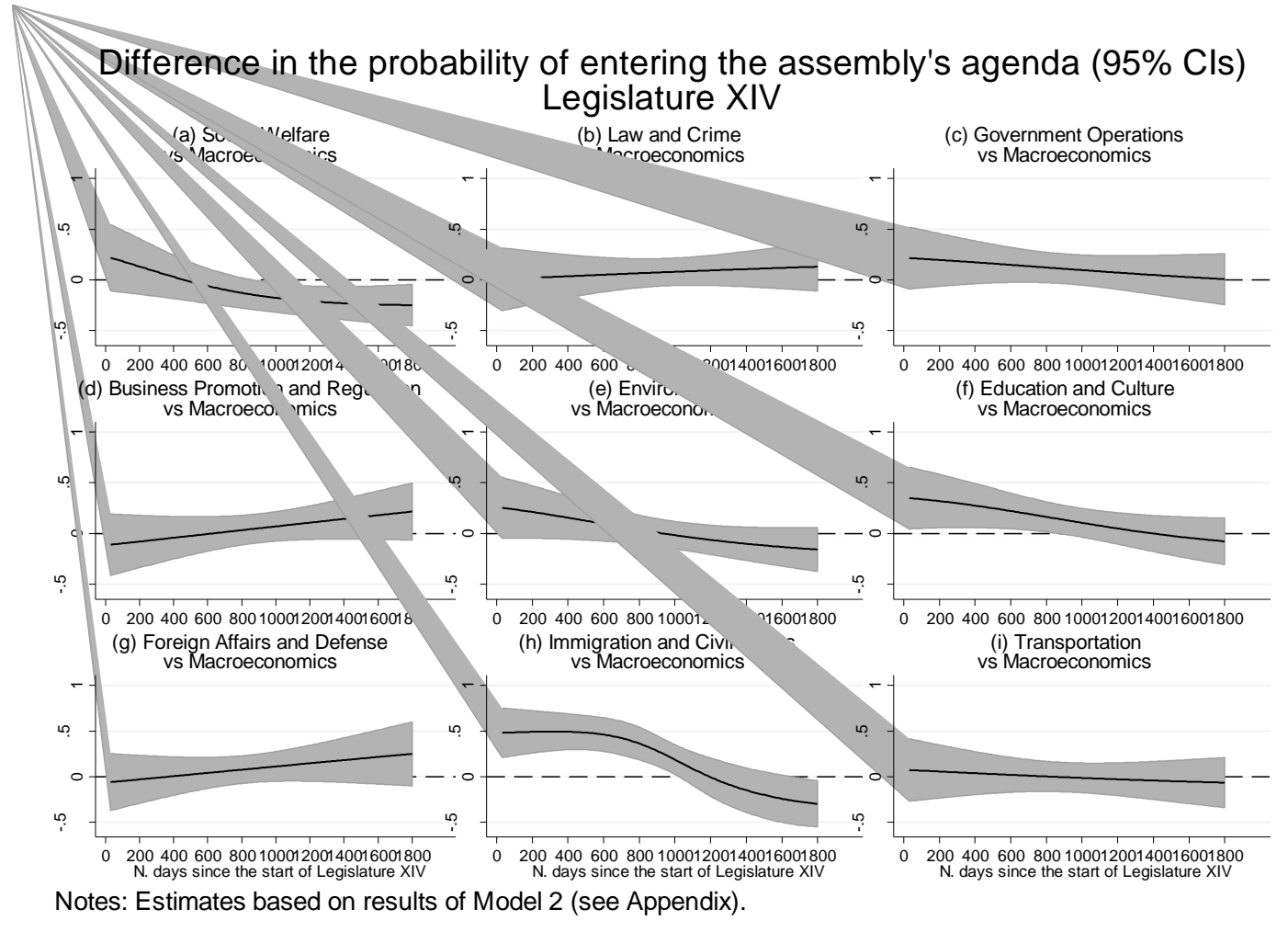


TABLE A1

DESCRIPTIVE STATISTICS

\begin{tabular}{|c|c|c|c|c|}
\hline & \multicolumn{2}{|c|}{ Legislature XVI } & \multicolumn{2}{|c|}{ Legislature XIV } \\
\hline Continuous Variables & Mean & SD & Mean & SD \\
\hline Number of committee referrals & 5.83 & 2.98 & 6.42 & 2.75 \\
\hline Pre-committee stage duration & 314.96 & 389.64 & 277.79 & 310.40 \\
\hline Discrete Variables & \multicolumn{2}{|c|}{ Per cent } & \multicolumn{2}{|c|}{ Per cent } \\
\hline Bill Type: Ordinary & \multicolumn{2}{|c|}{89.92} & \multicolumn{2}{|c|}{90.09} \\
\hline Bill Type: Conversion & \multicolumn{2}{|c|}{4.59} & \multicolumn{2}{|c|}{6.65} \\
\hline Bill Type: Constitutional & \multicolumn{2}{|c|}{6.49} & \multicolumn{2}{|c|}{3.26} \\
\hline Proposer: Majority & \multicolumn{2}{|c|}{47.30} & \multicolumn{2}{|c|}{55.72} \\
\hline Proposer: Opposition & \multicolumn{2}{|c|}{34.68} & \multicolumn{2}{|c|}{32.78} \\
\hline Proposer: Consensual & \multicolumn{2}{|c|}{18.02} & \multicolumn{2}{|c|}{11.50} \\
\hline Initiative: Government & \multicolumn{2}{|c|}{8.56} & \multicolumn{2}{|c|}{11.57} \\
\hline Initiative: MPs & \multicolumn{2}{|c|}{91.44} & \multicolumn{2}{|c|}{88.43} \\
\hline Government: Berlusconi II & \multicolumn{2}{|c|}{ - } & \multicolumn{2}{|c|}{88.91} \\
\hline Government: Berlusconi III & \multicolumn{2}{|c|}{ - } & \multicolumn{2}{|c|}{11.09} \\
\hline Government: Berlusconi IV & \multicolumn{2}{|c|}{75.32} & \multicolumn{2}{|c|}{ - } \\
\hline Government: Monti & \multicolumn{2}{|c|}{24.68} & \multicolumn{2}{|c|}{ - } \\
\hline
\end{tabular}


TABLE A2

MODELS ON THE SELECTION OF BILLS FOR DISCUSSION IN THE ASSEMBLY,
ITALIAN LEGISLATURE XVI (2008-2013) AND XIV (2001-2006)

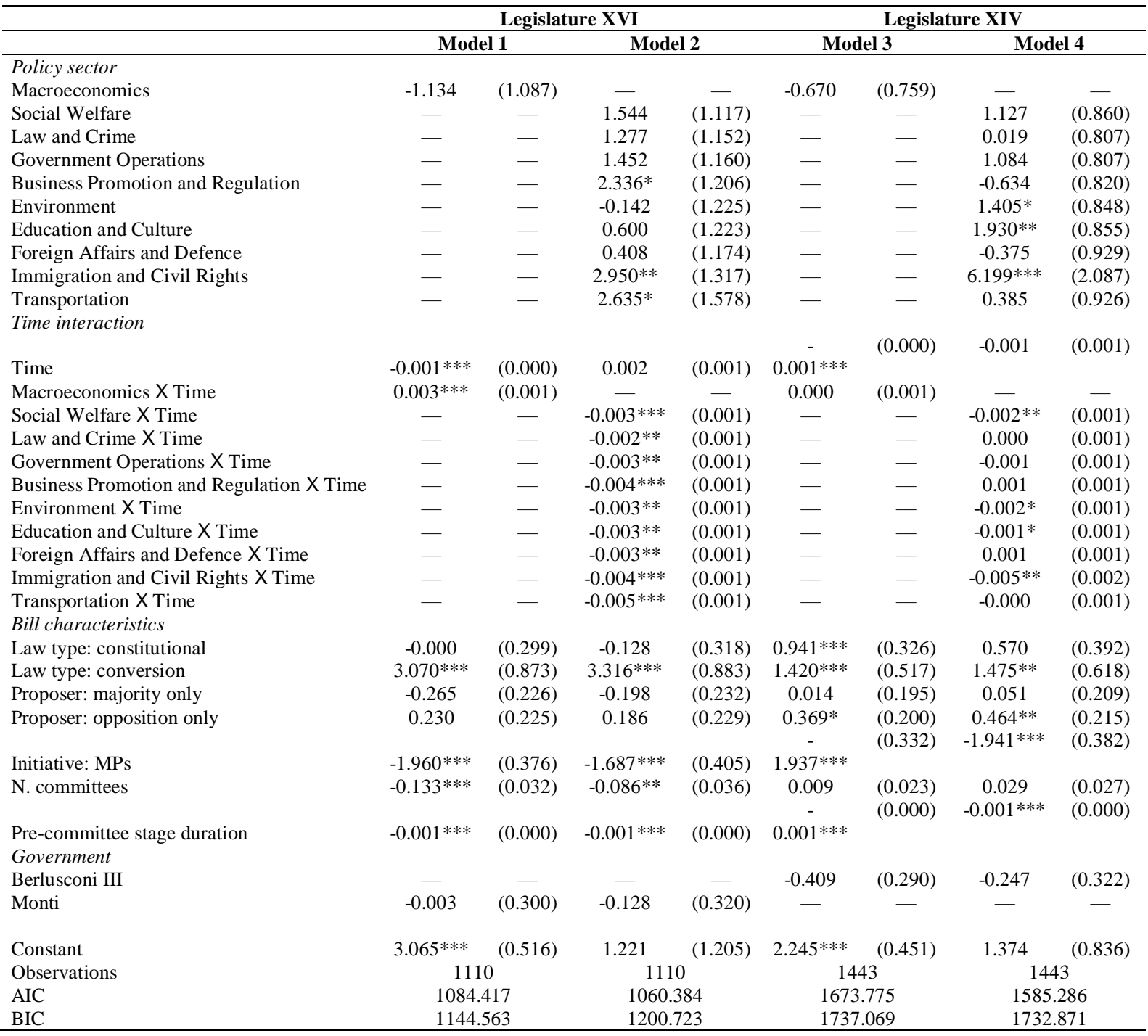

Notes: Coefficients of logistic regression. Baseline law type is "ordinary"; baseline proposer is "consensual" (majority and opposition together); baseline government is "Berlusconi IV" in Models 1 and 2, "Berlusconi II" in Models 3 and 4. In Models 1 and 3, the policy content of legislation is measured with the dummy Macroeconomics. In Models 2 and 4, policy content is operationalised using dummies for policy domains, with Macroeconomics as the omitted baseline category. Robust standard errors in parentheses. Statistical significance: ${ }^{*} \mathrm{p}<0.10,{ }^{* *} \mathrm{p}<0.05$, $* * * \mathrm{p}<0.01$. 